\title{
INVESTIGATING ON EFFECT OF HOT AIR AND WATER TEMPERATURE ON KINETIC OF REHYDRATION OF CELERY BY USING PELEG'S MODEL
}

\author{
A. SALIMI, H. AMERI and A. HAJIGHORBANI \\ Veterinary Department, Semanan University, Semann, Iran \\ Email: a.salimi@semnan.ac.ir,haniyeh.amery@gmail.com,atefe.hajighorbani75@gmail.com
}

\begin{abstract}
The Peleg model was used to determine effect of drying and rehydration conditions on celery samples. Cubes were dried in a hot air oven $\left(70^{\circ} \mathrm{C}\right.$ and $\left.90^{\circ} \mathrm{C}\right)$ and rehydrated by immersing in water $\left(25 \pm 2^{\circ} \mathrm{C}\right.$ and $\left.100 \pm 2^{\circ} \mathrm{C}\right)$. Results showed that the samples which were dried at $70{ }^{\circ} \mathrm{C}$ and rehydrated at $25^{\circ} \mathrm{C}$, reached to maximum moisture content after rehydration. Also, samples which were rehydrated at water temperature of $25^{\circ} \mathrm{C}$, had higher levels of rehydration ratio (RR) as a function of physical properties. The Peleg's rate constant $\left(K_{1}\right)$, decreased significantly while water temperature increased. Lower levels of $K_{1}$ indicate maximum rate of water absorption. In case of the Peleg capacity constant $\left(K_{2}\right)$, it increased slightly while water temperature increased. Increasing of $K_{2}$ values is a sign of less water absorption capacity. Finally, it was observed that the predicted and experimental values had a good correlation which indicates that the Peleg model was adequate to describe rehydration kinetics of celery cubes.
\end{abstract}

Keywords - Rehydration, Drying, Kinetic, Celery, Peleg model.

\section{INTRODUCTION}

Dehydration is an old process, which is used for extending shelf life, facilitate shipping and storage and produce new products. By drying food, they can be preserved due to reducing moisture content and therefore avoiding or limiting the microorganism growths and chemical reactions (Mujumdar, 1995, Conteras et al., 2008)

Celery (Apium graveolens L.) belongs to umbrelliferae plant. It is native to Mediterranean coastal marshes and nowadays is widely cultivated all around the world. It is rich in vitamins, inorganic salts, calcium, phosphorus, iron and essential oils (Engindeniz, 2008). It has been reported that celery can lower blood pressure as well as blood lipid and is also used as stimulants, antispasmodics, aphrodisiacs and so on (Kapoor and Bhatnagar, 2007).

Fresh celery contains high moisture content and it is difficult to control storage condition; so, to increase shelf life, some processes have to be used. Hot air drying is one of the most common processes which is used for different agricultural products (Yanishlieva-Maslarova, 2001). Shrinkage, disrupting the function of capillary tubes and some changes in physical properties of the samples may occur during drying (Maskan, 2001; Lewicki and Jakubczyk, 2004).

Dehydrated products are usually rehydrated prior to their use. Rehydration efficiency usually depends different parameters such as structural damages in vegetal tissues, soaking time and water temperature (Krokida and Marinos-Kouris, 2003, Ranjbari et al., 2011; Shafaei and Masoumi, 2013).

Generally, the soaking process is time consuming and takes up to 4 hours at room temperature. To minimize soaking time in water, higher water temperatures can be used (Cunningham et al., 2007; Kashaninejad et al., 2009; Shafaei and Masoumi, 2013; Khazaei and Mohammadi, 2009).

The relationship between moisture content during soaking and time is usually expressed by different models. Many theoretical and empirical approaches have been employed by now (Shafaei and Masoumi, 2014; Yildirim et al., 2013; Da Silva et al., 2013; Ghafoor et al., 2014).

One of the most popular models which has been used for modeling and analyzing water absorption kinetic of dried food, is the Peleg model. It is an empirical, nonexponential model which is illustrated as Eq. 1 (Peleg, 1988):

$$
X=X_{i}+t /\left(K_{1}+K_{2 *} t\right)
$$

where $X$ is moisture content at time $t, X_{i}$ is initial moisture content, $t$ is time, $K_{1}$ and $K_{2}$ are kinetic parameters of Peleg model which are related to equilibrium moisture content, $X_{e q}$, when $t \rightarrow \infty$.

Equilibrium moisture content can be calculated by:

$$
X_{e q}=X_{i}+1 / K_{2}
$$

Equation 1 can be linearized as Eq. 3:

$$
\mathrm{t} /\left(X-X_{i}\right)=K_{1}+K_{2} * t
$$

This model is commonly used to describe water absorption characteristics of different dried food during soaking and rehydration (Vasudeva et al., 2010; Salimi Hizaji et al., 2011; Montanuci et al., 2013; Ranjbari et al., 2013; Botelho et al., 2013; Oliveira et al., 2013 and Shafaei et al., 2016).

The rehydration ability of the dehydrated products is usually expressed by the rehydration ratio (RR), defined as Eq. 4:

$$
R R=(X+1) /\left(X_{i}+1\right)
$$


The purpose of this research was to determine the effect of experimental conditions (hot air temperature during drying and water temperature during rehydration) on kinetic of water absorption of dried celery by using Peleg model.

\section{Nomenclature:}

$X$ : moisture content ( $\mathrm{kg}$ water $/ \mathrm{kg}$ wet basis)

$X_{i}$ : initial moisture content ( $\mathrm{kg}$ water $/ \mathrm{kg}$ wet basis)

$X_{f}$ : moisture content of fresh sample ( $\mathrm{kg}$ water $/ \mathrm{kg}$ wet basis)

$X$ : equilibrium moisture content ( $\mathrm{kg}$ water $/ \mathrm{kg}$ wet basis)

$M$ : weight of sample $(\mathrm{kg})$

$M_{i}$ : initial weight of dried sample $(\mathrm{kg})$

$M_{f}$ : weight of fresh sample $(\mathrm{kg})$

$R R$ : rehydration ratio

$K_{1}$ : parameter of Peleg's model Eq. (kg wet basis $/ \mathrm{kg}$ water)

$K_{2}$ : parameter of Peleg's model Eq. (kg wet basis $/ \mathrm{kg}$ water

$t$ : time of rehydration (min)

$W A C$ : water absorption capacity

Pre: predicted moisture contents (kg water/kg wet basis)

Exp: experimented moisture contents ( $\mathrm{kg}$ water $/ \mathrm{kg}$ wet basis)

\section{П. METHODS}

\section{A. Martials}

Fresh celery was supplied from the agricultural center of Semnan (Iran). Initial moisture content was $94.09 \%$ (wet basis). Celeries were cut to $2 \times 1 \times 0.5 \mathrm{~cm}$ cubes. To inhibit browning, samples were blanched in water bath (Pars Azma-R.J.42) at $97 \pm 2^{\circ} \mathrm{C}$ for three minutes.

\section{B. Drying treatments}

To dry samples, a hot air oven (Memmert, D-91126) was used. Air temperature was set on 70 and $90^{\circ} \mathrm{C}$ to reach to $16 \%$ moisture content (wet basis).

\section{Rehydration}

The dried celery samples were rehydrated by immersing in distilled water at controlled temperatures. The time intervals for monitoring weight changes of the samples were one minutes and ten seconds for water temperature of $25 \pm 2^{\circ} \mathrm{C}$ and $100 \pm 2^{\circ} \mathrm{C}$ respectively (Cunningham et al., 2007; Maskan, 2001). Each experiment was performed in triplicate and graphs were carried out by Microsoft excel 2013.

\section{Rehydration kinetics}

As it is illustrated in Fig. 1, after rehydration, the highest final moisture content, belonged to the samples which were dried at $70{ }^{\circ} \mathrm{C}$ and rehydrated at $25^{\circ} \mathrm{C}$ water temperature. Totally, Samples which were rehydrated at hot water $\left(100^{\circ} \mathrm{C}\right)$, had the lowest moisture content and the ones which were rehydrated in lower water temperature $\left(25^{\circ} \mathrm{C}\right)$, had higher moisture contents.

Dried materials, especially the ones which are processed in hot air ovens, have low porosity and high apparent density (Krokida and Maroulis, 1997). In addition, destruction of texture and structure during drying processes, can affect water absorption negatively (Krokida et al., 1999; Lewicki and Jakubczyk, 2004). The main reason for this phenomenon is the shrinkage of the tissue due to loss of a large amount of free water as well as the inefficiency of capillary tubes due to shrinkage and precipitation of solid materials. So, in order to rehydrate dried food, usually samples should be immersed in water for longer times or higher water temperatures to be completely hydrated.

Observed results, showed that the samples which were dried at $70{ }^{\circ} \mathrm{C}$ and rehydrated at $25^{\circ} \mathrm{C}$, could absorb and keep more water in their tissues which resulted to higher moisture contents.

It is accepted that rehydration phenomenon is strongly related to the cellular and structural condition of the samples. Overall, during rehydration, three phenomena can happen which are penetration and Imbibition of water, swelling and leaching of soluble solids. It has been reported that at higher drying temperatures, shrinkage and severe structural damages might result to lower capability of cells to absorb and keep water molecules which lead to lower rehydration efficiency (Krokida and Philippopoulos, 2005). Also, although higher water temperatures can accelerate the rate of rehydration, but some structural damages might reduce the water holding capacity of the samples (Moreira et al., 2008).

Similar results were reported by Abu-Ghannam and McKenna (1997), Maharaj and Sankat (2000), García Pascual et al. (2005), Miranda et al. (2010), Vega-Gálvez et al. (2011) and Vega-Gálvez et al. (2015).

Results which are illustrated in Figs. 2 and 3, represent kinetic of moisture content changes during rehydration process. According to the obtained data, these diagrams have two main parts: an initial sharp slope at the beginning of process, followed by a slow and gradual increase of rehydration rate. At the beginning of rehydration process, samples have the lowest level of moisture content and the water flux in to the dried material is in the maximum rate but gradually, as the process progresses and the system becomes closer to equilibrium moisture content, the driving force which induce water transfer in to the dried tissue, decreases and finally result to lower rate of water absorption (Salimi Hizaji et al., 2010; Salimi Hizaji et al., 2011)

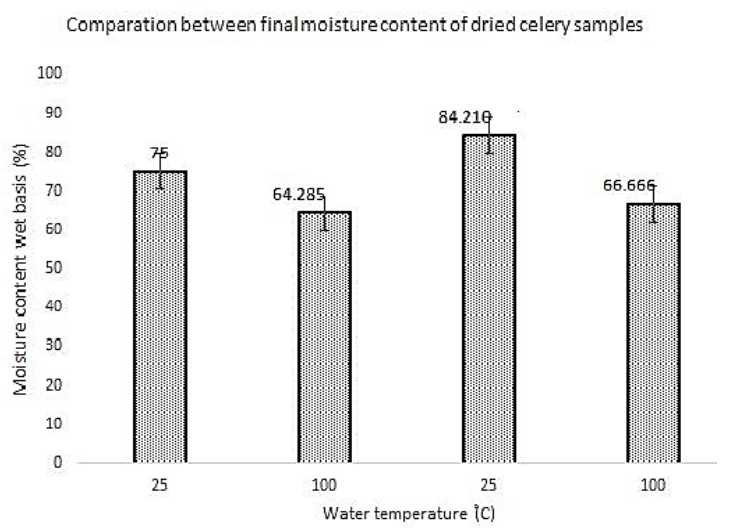

Fig. 1. Effect of drying and rehydration temperature on moisture content of samples. 


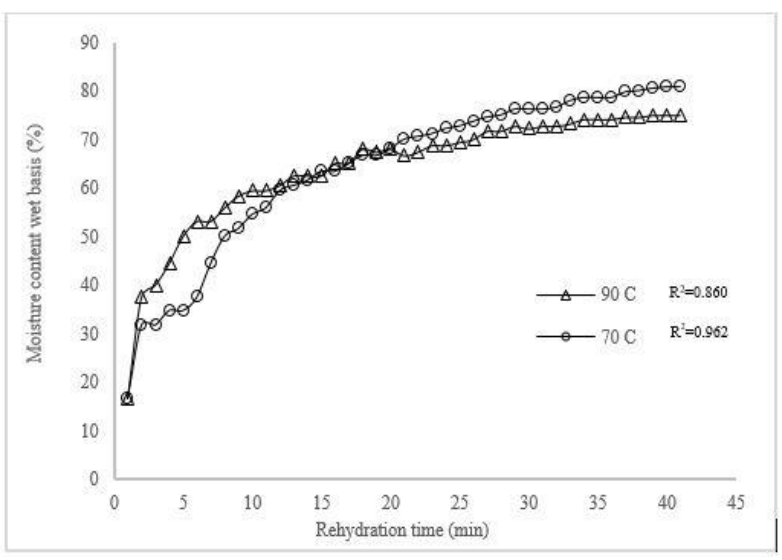

Fig. 2: Kinetic of moisture content changes during rehydration at $25^{\circ} \mathrm{C}$ water temperature.

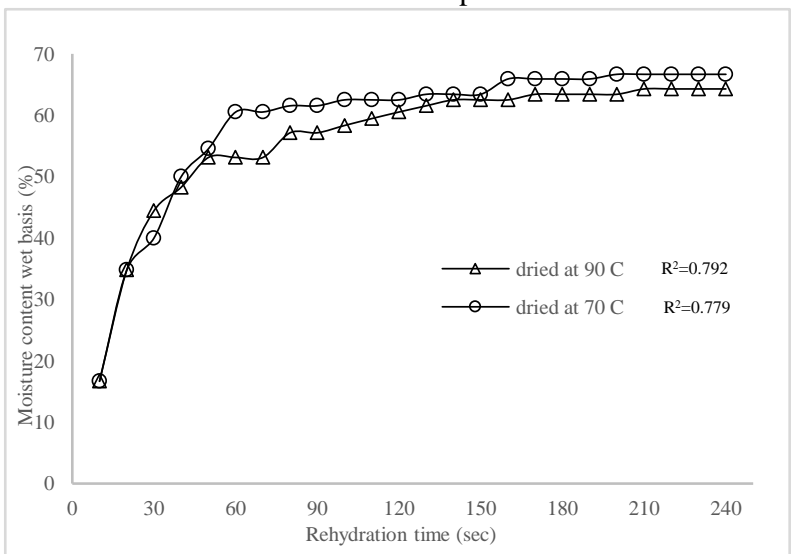

Fig. 3: Kinetic of moisture content changes during rehydration at $100{ }^{\circ} \mathrm{C}$ water temperature.

Table 1. Parameters and coefficients of determination of Eq. (1) for rehydration at two temperatures

\begin{tabular}{ccccc}
\hline $\begin{array}{c}\text { Drying hot air } \\
\text { temperature }\left[{ }^{\circ} \mathrm{C}\right]\end{array}$ & 90 & 90 & 70 & 70 \\
$\begin{array}{c}\text { Rehydration water } \\
\text { temperature }\left[{ }^{\circ} \mathrm{C}\right]\end{array}$ & 100 & 25 & 100 & 25 \\
\hline$K_{1}$ & 0.527 & 5.109 & 0.481 & 8.800 \\
$K_{2}$ & 0.0185 & 0.015 & 0.017 & 0.012 \\
$X_{e q}$ & 70.720 & 82.456 & 72.846 & 99.311 \\
\hline
\end{tabular}

\section{E. Peleg's modeling}

Parameters of Peleg's model were calculated according to Eq. (1). In order to do this, Eq. (1) was linearized to Eq. (3). Results have been shown in Table 1.

As it is illustrated in Table 1, the Peleg's rate constant $\left(K_{1}\right)$, decreased significantly while water temperature increased. It shows that water transfer (which is reversely related to $K_{1}$ ) was promoted by increasing water temperature. Also, the minimum calculated $K_{1}$, belonged to the sample which was dried at $70^{\circ} \mathrm{C}$ and rehydrated at $100^{\circ} \mathrm{C}$. Since lower levels of $K_{1}$ indicate the maximum rate of water absorption, it can be concluded that the samples which were dried at $70^{\circ} \mathrm{C}$, were in better structural conditions and had more efficient capillary tubes. Also these results confirm the positive effect of higher water temperatures on accelerating the rate of rehydration of dried celery samples.
Similar behavior of $K_{1}$ was found by other authors with regard to the rehydration of other products (Maskan, 2001; Turhan et al., 2002; García-Pascual et al., 2005; Djomdi and Ndjouenkeu, 2007; Moreira et al., 2008; Shafaei et al., 2016).

Results showed that $K_{2}$, (Peleg capacity constant), increased slightly while water temperature increased. That is a sign of lower water holding capacity of the rehydrated samples. $K_{2}$ changes depend on many different parameters such as type, structure and chemical composition of dried materials. Although higher water temperatures can increase rate of water absorption and result to faster hydration process, but it also can damage and demolish the structure which might affect water holding capacity and final moisture content, negatively.

As it is shown in Table 1 , the minimum value of $K_{2}$ belonged to the sample which was dried at $70^{\circ} \mathrm{C}$ and rehydrated at $25^{\circ} \mathrm{C}$. Since $K_{2}$ is related to water holding capacity, it can be concluded that the samples which were dried at $70^{\circ} \mathrm{C}$ and soaked in $25^{\circ} \mathrm{C}$ water, were more capable to keep and hold absorbed water due to less thermal damages during drying and having more efficient tubular tubes. Reversely, $K_{2}$ values increased for the samples which were dried and rehydrated at high temperatures which show the negative effect of sever heating on the structural capability of the samples for absorbing and holding water inside their textures. Same results were reported about chickpea (Turhan et al., 2002), carrot (Planinic et al., 2005) and strawberry (Ciurzynska and Lenart, 2009).

Figures 4 and 5 show that the predicted and experimented values had good correlation and high levels of $\mathrm{R}^{2}$ were observed for the samples. It indicates that the Peleg model is adequate to describe rehydration kinetics of celery cubes. Some other researchers have reported that this model can be used for chestnut (Moreira et al., 2008), tiger nut (Djomdi and Ndjouenkeu, 2007), potato (Salimi

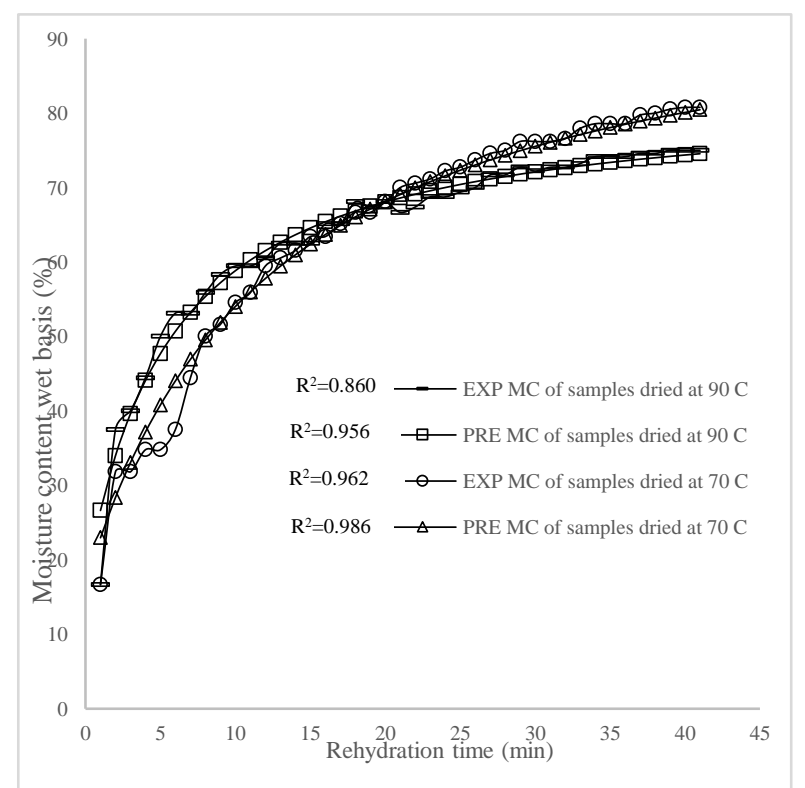

Fig. 4. Comparison between experimental and predicted moisture contents at $25^{\circ} \mathrm{C}$. 


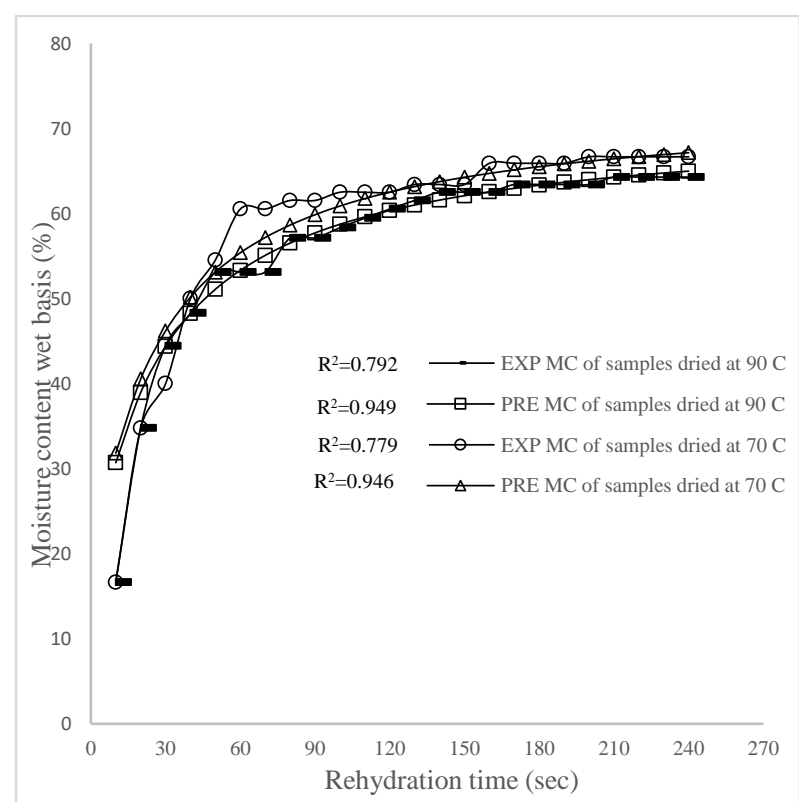

Fig. 5. Comparison between experimental and predicted moisture contents at $100^{\circ} \mathrm{C}$.

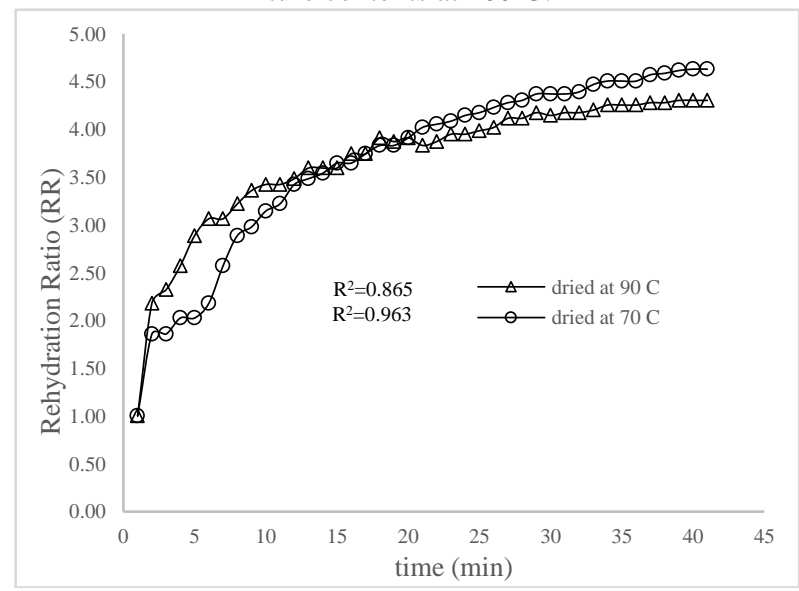

Fig. 6. Kinetic of RR changes of the samples rehydrated at $25^{\circ} \mathrm{C}$.

Hizaji et al., 2010 and 2011), amaranth leaves (Mujaffar and Lee Loy, 2016), Dumpling Wrapper (Chen et al., 2016), carrot (Kaleta et al., 2017) and edible films (Puscaselu, 2018) properly.

\section{E. Rehydration Ratio (RR):}

The rehydration ratio ranges between 1 and 5 for all the examined samples. Generally, dried celeries which were rehydrated at water temperature of $25^{\circ} \mathrm{C}$, had higher levels of $R R$.

$R R$ is a function of physical properties of samples and by reducing hydrophilic properties and water absorption efficiency, $R R$ decreases (Krokida and Marinos-Kouris, 2003). So according to calculated rehydration ratios, the samples which were dried at $70{ }^{\circ} \mathrm{C}$ and rehydrated at $25^{\circ} \mathrm{C}$ had the highest level of $R R(4.82 \pm 0.926)$ but samples which were dried at $90^{\circ} \mathrm{C}$ and rehydrated at $100{ }^{\circ} \mathrm{C}$ showed the lowest level of $R R(3.69 \pm 0.635)$. These results (see Figs. 6 and 7) confirmed that the samples which were dried under gentler situation at lower temperatures

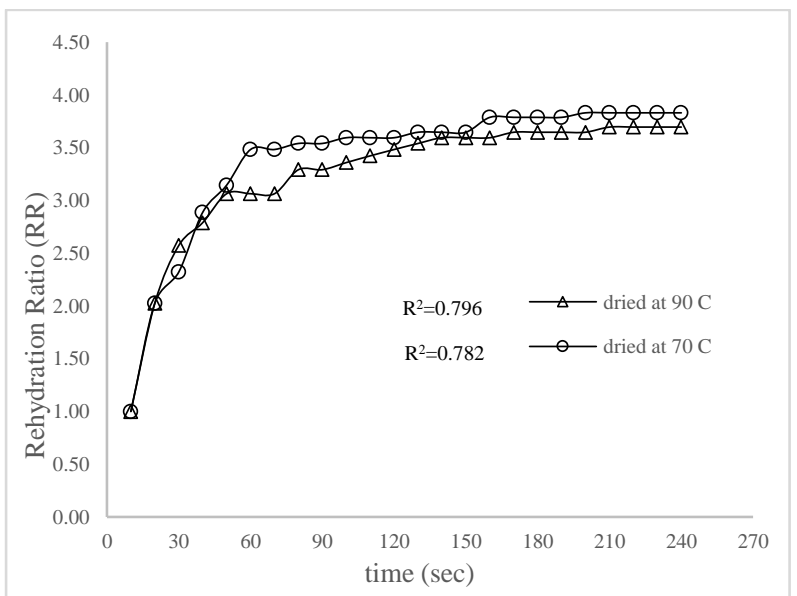

Fig. 7. Kinetic of RR changes of the samples rehydrated at $100^{\circ} \mathrm{C}$.

and rehydrated at temperate water, could absorb more water and reach to higher levels of moisture content and RR. These results were confirmed by other researchers (Jokic et al., 2009; Salimi Hizaji et al., 2010 and 2011; Doymaz, 2014).

\section{U. CONCLUSION}

The highest final moisture content belonged to the samples which were dried at $70{ }^{\circ} \mathrm{C}$ and rehydrated at $25^{\circ} \mathrm{C}$ water temperature. Usually dried products have low porosity and high density; In addition, destruction of texture and structure, can affect water absorption negatively. Obtained results showed that at water temperature of $25^{\circ} \mathrm{C}$, structural damages could be considered very low but it was remarkable at $100^{\circ} \mathrm{C}$. On the other hand, dried celeries which were rehydrated at water temperature of $25^{\circ} \mathrm{C}$, had higher levels of rehydration ratio $(R R)$. As $R R$ is a function of physical properties of samples, the ones which were dried at $70{ }^{\circ} \mathrm{C}$ and rehydrated at $25^{\circ} \mathrm{C}$ had the highest level of $R R(4.82 \pm 0.926)$ but the samples which were dried at $90{ }^{\circ} \mathrm{C}$ and rehydrated at $100{ }^{\circ} \mathrm{C}$ showed the lowest level of $R R(3.69 \pm 0.635)$.

The Peleg's rate constant $\left(K_{1}\right)$, decreased significantly while water temperature increased. It showed that water transfer was promoted by increasing water temperature. Also, the minimum amount of $K_{1}$ belonged to the sample which was dried at $70^{\circ} \mathrm{C}$ and rehydrated at $100^{\circ} \mathrm{C}$. Since higher levels $\mathrm{K}_{1}$ indicates the maximum rate of water absorption, it can be concluded that the samples which were dried at $70^{\circ} \mathrm{C}$, had better structural quality. The Peleg capacity constant $\left(K_{2}\right)$, increased slightly while water temperature increased. Increasing of $K_{2}$ values is a sign of lower water absorption capacity. This characteristic depends on many different parameters such as type, structure and chemical composition of samples. Since $K_{2}$ is related to water holding capacity, it can be concluded that the samples which were dried at $70^{\circ} \mathrm{C}$ had higher levels of water holding capacity due to less thermal damages on their structures during drying. Finally, it was concluded that Peleg model could be adequately fitted by experimental data and was adequate to describe kinetic of moisture content changes of celery cubes. 


\section{REFERENCES}

Abu-Ghannam, N. and McKenna B. (1997) "Hydration kinetics of red kidney beans (Phaseolus vulgaris L.)" J. Food Sci., 62, 520-523.

Botelho, F.M., Correa P.C., Martins M.A., Botelho S.D.C.C. and Oliveira G.H.H.D. (2013) "Effects of the mechanical damage on the water absorption process by corn kernel," Food Sci. Tech., 33, 282-288.

Chen, W., Li H., Jiao X. and Cui X. (2016) "Modeling of Rehydration of Freeze-dried Dumpling Wrapper," Research J. of Applied Sci., Eng. and Tech., 12, 556-561.

Ciurzynska, A. and Lenart A. (2009) "The influence of temperature on rehydration and sorption properties of freeze-dried strawberries," Croat. J. Food Sci. Tech, 1, 15-23.

Contreras, C., Martin-Esparza M.E., Chiralt A. and Martinez N.N. (2008) "Influence of microwave application on convective drying: Effects on drying kinetics, and optical and mechanical Properties of apple and strawberry," J. Food Eng., 88, 55-64.

Cunningham, S.E., McMinn W.A.M., Magee T.R.A. and Richardson P.S. (2007) "Modeling water absorption of pasta during soaking," J. Food Eng., 82, 600-607.

Da Silva, W.P., Silva C.M.D.P.S., De Sousa J.A.R. and Farias V.S.O. (2013) "Empirical and diffusion models to describe water transport into chickpea (Cicer arietinum L.)" Int. J. Food Sci. Tech., 48, 67-273.

Djomdi, R.E. and Ndjouenkeu R. (2007) "Soaking behavior and milky extraction performance of tiger nuts (Cyperus esculentus) tubers," J. Food Eng., 78, 546-550.

Doymaz, I. (2014) "Drying Kinetics and Rehydration Characteristics of Convective Hot-Air Dried White Button Mushroom Slices," J. Chem., 2014, 1-8.

Engindeniz, S. (2008) "Economic analysis of agrochemical use for weed control in field-grown celery: A case study for Turkey," Crop Prot., 27, 377-384.

García-Pascual, P., Sanjuán N., Bon J., Carreres J.E. and Mulet A. (2005) "Rehydration process of Boletus edulis mushroom: characteristics and modeling," $J$. Food \& Agri., 85, 1397-1404.

Ghafoor, M., Misra N.N., Mahadevan K. and Tiwari B.K. (2014) "Ultrasound assisted hydration of navy beans (Phaseolus vulgaris)" Ultrason. Sonochem, 21, 409-414.

Jokić, S., Mujić I., Martinov M., Velić D., Bilić M. and Lukinac J. (2009) "Influence of Drying Procedure on Color and Rehydration Characteristic of Wild Asparagus," Czech J. Food Sci., 27, 171-177.

Kaleta, A., Gornicki K., Choinska A., Kosiorek K. and Czyzewska A. (2017) "Modelling of rehydration kinetics of dried carrots using the Peleg model," AgriForest Eng., 69, 13-21.

Kapoor, R. and Bhatnagar A.K. (2007) "Attenuation of cadmium toxicity in mycorrhizal celery (Apium
graveolensL.)" World J. Microb. Biot., 23, 1083-1089.

Kashaninejad, M., Dehghan A.M. and Khashiri M. (2009) "Modeling of wheat soaking using two artificial neural networks (MLP and RBF)" J. Food Eng., 91, 602-607.

Khazaei, J. and Mohammadi N. (2009) "Effect of temperature on hydration kinetics of sesame seeds (Sesamum indicum L.)" J. Food Eng., 91, 542-552.

Krokida, M.K., Kiranoudis C.T. and Maroulis Z.B. (1999) "Viscoelastic behavior of dehydrated products during rehydration," J. Food Eng., 40, 269277.

Krokida, M.K. and Marinos-Kouris D. (2003) "Rehydration kinetics of dehydrated products," J. Food Eng. 57, 1-7.

Krokida, M.K. and Maroulis Z.B. (1997) "Effect of drying method on shrinkage and porosity," J. Drying Tech., 15, 1145-1155.

Krokida, M.K. and Philippopoulos C. (2005) "Rehydration of Dehydrated Foods," Drying Technol., 23,799-830.

Lewicki, P.P. and Jakubczyk E. (2004) "Effect of hot air temperature on mechanical properties of dried apples," J. Food Eng., 64, 307-314.

Maharaj, V. and Sankat C.K. (2000) "The rehydration characteristics and quality of dehydrated dasheen leaves," J. Canadian Agri. Eng., 42, 81-85.

Maskan, M (2001) "Drying shrinkage and rehydration characteristics of kiwifruits during microwave drying," J. Food Eng., 48, 177-182.

Miranda, M., Vega-Gálvez A., García P., Di Scala K., Shi J., Xue S. and Uribe E. (2010) "Effect of Temperature on Structural Properties of Aloe vera (Aloe barbadensis Miller) Gel and Weibull Distribution for Modelling Drying Process," Food Bioprod. Proc., 88, 138-144.

Montanuci, F.D., Jorge L.M.D.M. and Jorge R.M.M. (2013) "Kinetic, thermodynamic properties, and optimization of barley hydration," Food Sci. Technol., 33, 690-698.

Moreira, R., Chenlo F., Chaguri L. and Fernandes C. (2008) "Water absorption, texture and color kinetics of air- dried chestnuts during rehydration," J. Food Eng., 86, 584-594.

Mujaffa, S. and Lee Loy A. (2017) “The rehydration behavior of microwave- dried amaranth (Amaranthus dubius) leaves," Food Sci. \& Nut., 5,399-406.

Mujumbar, A.S. (1995).Handbook of industrial drying (second Ed.). New York, Marcel Dekker

Oliveira, A.L., Colnaghi B.G., Silva E.Z.D., Gouvea I.R., Vieira R.L. and Augusto P.E.D. (2013) "Modelling the effect of temperature on the hydration kinetic of adzuki beans (Vigna angularis)" Food Eng., 118, 417-420.

Peleg, M.A (1988) "Empirical model for the description of moisture sorption curves," J. Food Sci., 53, 1216-1219. 
Planinic, D., Velic S.T.., Bilic M. and Bucic A. (2005) "Modelling of drying and rehydration of carrots using Peleg's model," J. European Food Res. \& Tech., 221, 446-451.

Puscaselu, R. (2018) “Application of Biopolymers in Designing Completely Soluble Materials for Food Product Packaging,” J. App. Pack. Res., 10, 98-106.

Ranjbari, A., Kashaninejad M., Alami M. and Khomeiri M. (2011) "Effect of ultrasound pretreatment on water absorption characteristic of pea during steeping process," J. Food Process. Preserv., 2, 91-105.

Ranjbari, A., Kashaninejad M., Alami M., Khomeiri M. and Gharekhani M. (2013) "Effect of ultrasonic pre-treatment on water absorption characteristics of chickpeas (Cicer arietinum)" Lat. Am. Appl. Res., 43, 153-159.

Salimi Hizaji, A., Maghsoudlou Y. and Jafari S.M. (2010) "Application of Peleg model to study effect of water temperature and storage time on rehydration kinetics of air dried potato cubes," Lat. Am. Appl. Res., 40, 131-136.

Salimi Hizaji, A., Maghsoudlou Y. and Jafari S.M. (2011) "Effect of water temperature, variety and shelf life on rehydration kinetics of microwave dried potato cubes," Lat. Am. Appl. Res., 41, 249 254.

Shafaei, S.M. and Masoumi A.A. (2013) "Modeling of water absorption of bean during soaking," International Conference on Agricultural Engineering: New Technologies for Sustainable Agricultural Production and Food Security, Muscat, Oman.

Shafaei, S.M. and Masoumi A.A. (2014) "Evaluation of Khazaei model in predicting of water absorption of chickpea during soaking," Agric. Adv., 3, 1-8.

Shafaei, S.M., Masoumi A.A. and Roshan H. (2016) "Analysis of water absorption of bean and chickpea during soaking using Peleg model," J. Saudi Society of Agri. Scie., 15, 135-144.

Turhan, M., Sayar S. and Gunasekaran S. (2002) "Application of Peleg model to study water absorption in chickpea during soaking," J. Food Eng., 53, 153159.

Vasudeva, S., Vishwanathan K.H., Aswathanarayana K.N. and Indhudhara Swamy Y.M. (2010) "Hydration behaviour of food grains and modelling their moisture pick up as per Peleg's equation: part I. Cereals," J. Food Sci. Technol., 47, 34-41.

Vega-Gálvez, A., Zura-Bravo L., Lemus-Mondaca R., Martinez-Monzó J., Quispe-Fuentes I., Puente L. and Di Scala K. (2015) "Influence of drying temperature on dietary fibre, rehydration properties, texture and microstructure of Cape gooseberry (Physalis peruviana L.)" J. Food Sci. Technol., 52, 2304-2311.

Vega-Gálvez, A., Ah-hen K., Chacan M., MartínezMonzó J., García-Segovia P., Lemus-Mondaca R. and Di Scala K. (2011) "Effect of temperature and air velocity on drying kinetics, antioxidant capacity, total phenolic content, color, texture and microstructure of apple (var. Granny Smith) slices," Food Chem., 132, 51-59.

Yanishlieva-Maslarova, N.V. (2001). Inhibiting Oxidation: Antioxidants in Foods, CRC Press, Boca Raton, FL.

Yildirim, A., Oner M.D., and Bayram M. (2013) "Effect of soaking and ultrasound treatments on texture of chickpea," J. Food Sci. Technol., 50, 455-465.

\author{
Received: October 7, 2018 \\ Sent to Subject Editor: May 9, 2019 \\ Accepted: September 11, 2019
}

Recommended by Subject Editor: M. Luján Ferreira 